\title{
INFLUENCE OF SOWING TIME BASED TEMPERATURE ON FLOWERING AND SEED YIELD OF FRENCH BEAN (Phaseolus vulgaris L.)
}

\author{
S.S. Kakon", M.S.A. Khan, J.A. Choudhury, M.Z. Ali, and M.A. Aziz \\ Agronomy Division, Bangladesh Agricultural Research Institute
}

\begin{abstract}
A field experiment was conducted at the research field of Agronomy Division, BARI, Joydebpur, Gazipur during rabi season of 2015-16 to evaluate the flowering behavior and seed yield of French bean. Three varieties viz., BARI Jharsheem-1, BARI Jharsheem-2 and BARI Jharsheem-3 were sown at 15 November, 30 November, 15 December and 30 December for getting temperature variation. Sowing dates based temperature variation, significantly affect the flowering behaviour and seed yield of French bean varieties. Flowering duration of 15 November and 30 November sowings were longer due to prevailing low temperatures (Min.11.72-13.24 ${ }^{\circ} \mathrm{C}$ and Max. 25.02-25.82 ${ }^{\circ} \mathrm{C}$ ). On the contrary, minimum flowering duration was recorded in 30 December sown crop (11-17 days). Minimum duration might be due to prevailing high temperature (Min. $16.05-18.61^{\circ} \mathrm{C}$ and Max. $28.89-31.31^{\circ} \mathrm{C}$ ) that shorten the flowering duration of all French bean varieties. November sowing performed better in relation to yield components and seed yield than other sowing. BARI Jharsheem-1 produced the maximum seed yield (1734 kg ha-1) in 15 November which was statistically similar to 30 November sowing $\left(1620 \mathrm{~kg} \mathrm{ha}^{-1}\right)$. The lowest seed yield $\left(421 \mathrm{~kg} \mathrm{ha}^{-1}\right)$ was produced in BARI Jharsheem -2 from 30 December sowing. The highest seed yield was obtained from November sowing might be due to favourable optimum temperature for better flowering and pod setting that resulted in maximum seed.
\end{abstract}

Keywords: Phenology, temperature, flowering, yield, french bean, varieties

\section{INTRODUCTION}

French bean (Phaseolus vulgaris L.) is cultivated in Bangladesh as green bean as well as dry seeds. The mature seeds could be used for preparing dal. The crop has gained popularity for its short durability and high nutritive value. Green pods are rich in vitamins, protein and minerals which is also consumed as soup. French bean can

*Corresponding author email: kakonbari@gmail.com

Received: 04.01.2016 
play an important role to overcome the national protein deficit. Late sowing is one of the major causes of low yield of French bean. In Bangladesh, it is usually cultivated after T. Aman harvest. If delay of T. Aman harvest than the crop faces unfavorable weather conditions at its reproductive phase and gave low yield. Among the weather factors, mainly air temperature and rainfall greatly affect the growth and development of bean plants (Gross and Kigel, 1994; Mouhouche et al., 1998; Ibarra Perez et al., 1999). Sowing at proper time allows sufficient growth and development of a crop to obtain a satisfactory yield because high temperature is one of the major environmental stresses that affect plant growth and development (Boyer, 1982). The optimum temperature range for optimum bean growth is $16-30^{\circ} \mathrm{C}$ (Nonneck, 1989). High temperature stress causes substantial loss in crop yield due to damage of reproductive organs (Savin and Nicolas, 1996) and reduced length of reproductive period. So, it is essential to study the crop growth behaviours in changing climatic condition. Therefore, the present experiment was conducted to evaluate the flowering pattern and seed yield under different temperature variation from different sowing time.

\section{MATERIALS AND METHODS}

The experiment was conducted at the Agronomy research field of Bangladesh Agricultural Research Institute (BARI), Joydebpur, Gazipur during rabi season of 2015-2016. The experiment site was located at Chhiata Series under Agro-Ecological Zone-28 (AEZ-28), latitude $23^{0} 59 / \mathrm{N}$ and longitude $90^{\circ} 24 / \mathrm{E}$. Before opening the land, the soil samples were taken from the spots of the experimental area and analyzed from the Soil Science Division, BARI. The soil analysis showed that the soil of the experimental field was loam in texture and low in organic matter $(1.27 \%)$. The soil was acidic in nature with $\mathrm{pH}(6.1)$ and contained very low amount of total nitrogen $(0.067 \%)$, phosphorus $(9.6 \%)$, sulphur $(12 \%)$, zinc $(2 \mathrm{meq} / 100 \mathrm{~g})$ and medium amount of potassium $(0.18 \mathrm{meq} / 100 \mathrm{~g})$. The treatments consisted of four sowing dates at 15 days interval starting from 15 November and end on 30 December in main plot while sub-plot comprises of three varieties (var. BARI Jharsheem-1, BARI Jharsheem-2 and BARI Jharsheem-3) with replicated thrice. The experiment was laid out in a split- plot design. The unit plot size was $3.0 \mathrm{~m}$ x $3.0 \mathrm{~m}$. The crop was fertilized with 120-40-60-12-3 kg N-P-K-S-Zn /ha, respectively (FRG, 2012). Half of $\mathrm{N}$ and full doses of other fertilizers were applied at the time of final land preparation and the rest urea was top dressed at 35 days after sowing (DAS). Seeds was treated with vitavax and sown continuously in $30 \mathrm{~cm}$ apart rows. Plant to plant

distance was maintained by $15 \mathrm{~cm}$. Hand weeding was done at 25 and 40 days after sowing (DAS). Pre sowing irrigation was given to the crop for uniform emergence. The crops were attacked by cutworm (Agrotis ipsilon) and hairy caterpillar (Spilarctia obliqua) at early growth (vegetative) stage. The cutworm was controlled through hand picking. Perfecthion 40 EC @ $2.0 \mathrm{ml} \mathrm{l}^{-1}$ of water was sprayed at an interval of 7-10 days for 3 times to control hairy caterpillar. Matured pods were 
counted at harvest and pod abscission percentage was calculated as the formula given by Saha (2003).

Pod abscission $(\%)=[$ Total open flowers- total matured pods $] /$ (total open flowers) $\times 100$.

At each harvesting time, five plants were harvested randomly from each plot to record the data on yield components. Seed yield was recorded from an area of $2 \mathrm{~m} \mathrm{x}$ $2 \mathrm{~m}$ avoiding border effect. Data on different parameters were subjected to analysis of variance and the treatment means were compared by Least Significant Difference (LSD) test.

\section{RESULTS AND DISCUSSION}

Crop developmental events and growth duration were influenced by prevailing temperature variations (Table 1). Crop growth duration was recorded maximum in BARI Jharsheem-2 sown on 15 November (107 days) followed by 30 November sowing (104 days). The minimum duration (76 days) was recorded in BARI Jharsheem-3 at 30 December sowing. The reasons for variation in growth duration might be due to increased day and night temperature. The late sown crops flowered earlier with reduced vegetative durations than those of early sown ones. The highest duration from emergence to first flowering was recorded in 30 November (39-43 days) sowing. The lowest duration for flowering was recorded (32-38 days) in 30 December sowing.

Table 1. Crop development events and crop duration of French bean varieties as affected by sowing date

\begin{tabular}{lcccc}
\hline $\begin{array}{c}\text { Sowing date } \\
\text { variety }\end{array}$ & Emergence & $\begin{array}{c}\text { Days to 1st } \\
\text { flowering }\end{array}$ & $\begin{array}{c}\text { Flowering duration } \\
\text { (Day) }\end{array}$ & $\begin{array}{c}\text { Crop growth duration } \\
\text { (Day) }\end{array}$ \\
\hline $\mathrm{D}_{1} \times \mathrm{V}_{1}$ & 6 & 32 & 25 & 100 \\
$\mathrm{D}_{1} \times \mathrm{V}_{2}$ & 6 & 35 & 29 & 107 \\
$\mathrm{D}_{1} \times \mathrm{V}_{3}$ & 6 & 29 & 20 & 100 \\
$\mathrm{D}_{2} \times \mathrm{V}_{1}$ & 6 & 41 & 25 & 101 \\
$\mathrm{D}_{2} \times \mathrm{V}_{2}$ & 6 & 43 & 30 & 104 \\
$\mathrm{D}_{2} \times \mathrm{V}_{3}$ & 6 & 39 & 21 & 96 \\
$\mathrm{D}_{3} \times \mathrm{V}_{1}$ & 7 & 39 & 21 & 86 \\
$\mathrm{D}_{3} \times \mathrm{V}_{2}$ & 7 & 40 & 22 & 92 \\
$\mathrm{D}_{3} \times \mathrm{V}_{3}$ & 7 & 37 & 15 & 88 \\
$\mathrm{D}_{4} \times \mathrm{V}_{1}$ & 8 & 36 & 17 & 84 \\
$\mathrm{D}_{4} \times \mathrm{V}_{2}$ & 8 & 38 & 15 & 86 \\
$\mathrm{D}_{4} \times \mathrm{V}_{3}$ & 8 & 32 & 11 & 76 \\
\hline
\end{tabular}

$\mathrm{V}_{1=}$ BARI Jharsheem -1, $\mathrm{V}_{2=}$ BARI Jharsheem -2, $\mathrm{V}_{3=}$ BARI Jharsheem -3,

$D_{1}=15$ November, $D_{2}=30$ November, $D_{3}=15$ December, $D_{4}=30$ December. 
Temperature is an important factor of flowering in French bean (Table 2). Flowering duration in all varieties was also observed maximum in November sowing (20-30 days). Flowering duration of 15 November and 30 November sowings were longer due to prevailing low temperatures (Min.11.72-13.24 ${ }^{\circ} \mathrm{C}$ and Max 25.02$\left.25.82^{\circ} \mathrm{C}\right)$. On the contrary, minimum flowering duration was recorded in 30 December sown crop (11-17 days). Minimum duration might be due to prevailing high temperature (Min. $16.05-18.61^{\circ} \mathrm{C}$ and $\operatorname{Max} 28.89-31.31^{\circ} \mathrm{C}$ ) that shorten the flowering duration of all varieties. Similar results were also observed by Helena Łabuda and Anna Brodaczewska (2007).

Table 2. Prevailing average temperature during flowering duration of French bean varieties grown at different dates

\begin{tabular}{c|cc|c|c|cc}
\hline \multirow{2}{*}{ Sowing Date } & \multicolumn{6}{|c}{ Flowering duration } \\
\cline { 2 - 7 } & \multicolumn{2}{|c|}{ BARI Jharsheem -1 } & \multicolumn{2}{c}{ BARI Jharsheem -2 } & \multicolumn{2}{c}{ BARI Jharsheem -3 } \\
\cline { 2 - 7 } & Max. Tem. ${ }^{0} \mathrm{C}$ & $\begin{array}{c}\text { Min. Tem. } \\
{ }^{0} \mathrm{C}\end{array}$ & $\begin{array}{c}\text { Max. Tem. } \\
{ }^{0} \mathrm{C}\end{array}$ & $\begin{array}{c}\text { Min. Tem. } \\
{ }^{0} \mathrm{C}\end{array}$ & $\begin{array}{c}\text { Max. Tem. } \\
{ }^{0} \mathrm{C}\end{array}$ & $\begin{array}{c}\text { Min. Tem. } \\
{ }^{0} \mathrm{C}\end{array}$ \\
\hline 15 November & 25.56 & 11.74 & 25.02 & 11.72 & 25.52 & 11.78 \\
30 November & 25.18 & 12.10 & 25.82 & 13.24 & 24.26 & 11.41 \\
15 December & 27.82 & 15.07 & 28.75 & 16.11 & 26.38 & 12.74 \\
30 December & 30.87 & 18.41 & 31.31 & 18.61 & 28.89 & 16.05 \\
\hline
\end{tabular}

Table 3. Total dry matter production of French bean as affected by variety and sowing date

\begin{tabular}{c|c|c|c|c|c}
\hline \multirow{2}{*}{$\begin{array}{c}\text { Sowing date } \\
\times \text { variety }\end{array}$} & \multicolumn{5}{|c}{ Total dry matter $\left(\mathrm{g} / \mathrm{m}^{-2}\right)$} \\
\cline { 2 - 6 } & 20 DAS & 35 DAS & 50 DAS & 65 DAS & 80 DAS \\
\hline $\mathrm{D}_{1} \times \mathrm{V}_{1}$ & 31.81 & 77.52 & 150.07 & 254.83 & 282.17 \\
$\mathrm{D}_{1} \times \mathrm{V}_{2}$ & 28.43 & 72.63 & 152.53 & 240.37 & 270.53 \\
$\mathrm{D}_{1} \times \mathrm{V}_{3}$ & 29.52 & 68.67 & 142.50 & 224.24 & 240.40 \\
$\mathrm{D}_{2} \times \mathrm{V}_{1}$ & 29.17 & 74.50 & 146.13 & 248.17 & 274.87 \\
$\mathrm{D}_{2} \times \mathrm{V}_{2}$ & 27.33 & 71.57 & 136.50 & 227.27 & 257.13 \\
$\mathrm{D}_{2} \times \mathrm{V}_{3}$ & 26.00 & 64.67 & 116.83 & 211.07 & 231.77 \\
$\mathrm{D}_{3} \times \mathrm{V}_{1}$ & 21.71 & 61.33 & 112.82 & 200.53 & 254.23 \\
$\mathrm{D}_{3} \times \mathrm{V}_{2}$ & 18.00 & 60.67 & 88.80 & 182.80 & 216.13 \\
$\mathrm{D}_{3} \times \mathrm{V}_{3}$ & 15.33 & 48.04 & 78.03 & 152.50 & 178.57 \\
$\mathrm{D}_{4} \times \mathrm{V}_{1}$ & 15.66 & 45.99 & 86.33 & 161.87 & 187.33 \\
$\mathrm{D}_{4} \times \mathrm{V}_{2}$ & 13.33 & 38.31 & 68.33 & 126.25 & 146.13 \\
$\mathrm{D}_{4} \times \mathrm{V}_{3}$ & 12.00 & 27.56 & 79.70 & 152.83 & 158.53 \\
$\mathrm{LSD}(0.05)$ & - & - & 12.70 & 4.18 & 9.78 \\
$\mathrm{CV}(\%)$ & 11.40 & 5.08 & 6.48 & 4.22 & 5.51 \\
\hline
\end{tabular}




\section{Total dry matter production}

The interaction of sowing date and variety had significant effect on total dry matter (TDM) production at 50,65 and 80 DAS, except 20 and 30 DAS (Table 3). At the growth stages of 50,65 and 80 DAS, the highest TDM were recorded 150.07, 254.57 and $282.17 \mathrm{~g} \mathrm{~m}^{-2}$, respectively in BARI Jharsheem-1 sown on 15 November $\left(\mathrm{D}_{2}\right)$ which was identical with the dry matter produced by the same variety sown on 30 November. At $80 \mathrm{DAS}$, the lowest dry matter of $146.13 \mathrm{~g} \mathrm{~m}^{-2}$ was produced by BARI Jharsheem-2 sown on 30 December $\left(\mathrm{D}_{4}\right)$. Among the varieties, BARI Jharsheem-1 sown at different dates accumulated more dry matter at all stages. This might be due to genetic potentially of the variety (Ali and Tripathi, 1988).

\section{YIELD AND YIELD COMPONENTS}

Yield and yield attributes of French bean varieties were significantly affected by different sowing dates (Table 4). BARI Jharsheem-1 produced the tallest plant $(52.33 \mathrm{~cm})$ in 15 November sowing. The shortest plant $(22.33 \mathrm{~cm})$ was obtained in BARI Jharsheem-2 sown on 30 December. The number of flowers plant ${ }^{-1}$ was significantly affected by the different sowing dates and varieties. BARI Jharsheem -2 produced maximum and identical number of flowers plant $^{-1}$ (42.56 and 40.72) when sowing done on 15 November and 30 November and the lowest (15.03) also recorded in BARI Jharsheem-2 sown on 30 December. The result was in full agreement with that Graham (1979) who reported that French bean plants did not flower at $35-25^{\circ} \mathrm{C}$ but flowered at day-night temperature of $25-15^{\circ} \mathrm{C}$. The variation of flowering might be due to variations in temperature due to sowing dates. Significantly the highest number of pods plant ${ }^{-1}$ (15.83) was recorded in BARI Jharsheem-1 sown on 15 November. The lowest (3.47) number of pods plant ${ }^{-1}$ was obtained in BARI Jharsheem-2 sown on 30 December followed by BARI Jharseem-3 of same sowing date due to high temperature (Figure1). The lowest \% pod abscission (59.29) was observed in BARI Jharsheem-1 from 15 November sowing. Both BARI Jharsheem-2 and BARI Jharsheem-3 produced the highest pod abscission in 30 December sowing. Heitholt et al. (1986) also reported that late flowers aborted more frequently than did early flowers in soybean. Pod abscission was increased by delay sowing which was accordance with Fisher (1980). The number of seeds pod $^{-1}$ also significantly differed by sowing date and varieties (Table 4). The var. BARI Jharsheem-1 produced maximum number of seeds $\operatorname{pod}^{-1}(5)$ irrespective of sowing dates while the lowest (3) was produced in BARI Jharsheem-2 in 30 December sowing. The 100-seed weight of French bean was also significantly affected by different sowing dates and varieties. The 100-seed weight decreased with delay sowing. Weight of 100 -seed was maximum (35.26g) in BARI Jharsheem -3 sown on 15 November followed by same variety sown on30 November. The lowest seed weight $(16.45 \mathrm{~g})$ was produced in BARI Jharsheem-2 in 30 December sowing. November sowing received lower day and night temperature that causes longer crop growth duration and ultimately more TDM production and translocation to pods. On the other hand, December sowing 
received higher day and night temperature that hasten forced maturity and reduced TDM production and translocation to the yield components.

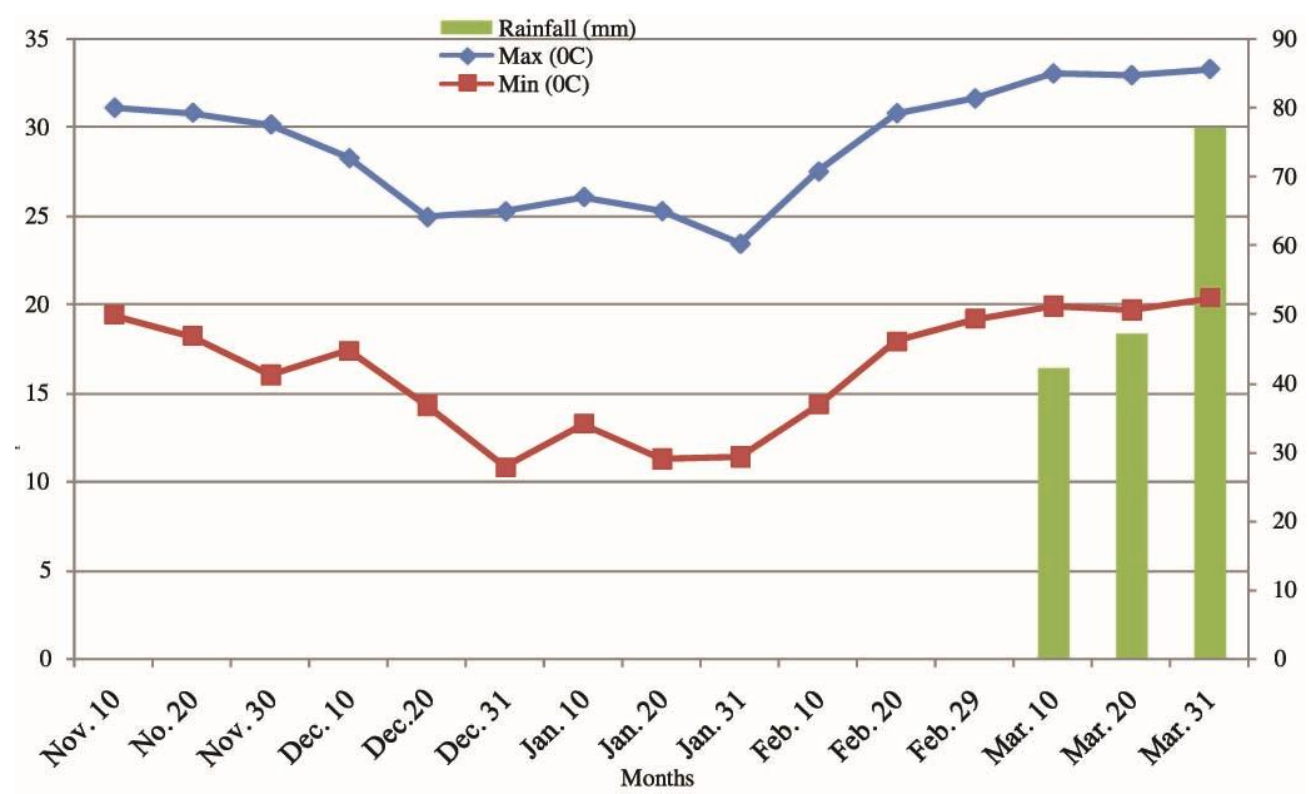

Figure 1. Decadal mean temperatures (min \& max) and monthly total rainfall during crop growing periods

Seed yield is the function of number of pods plant ${ }^{-1}$, seeds pod $^{-1}$ and 100 -seed weight. Seed yield decreased with delay sowing. Seed yield was found maximum (1734 $\left.\mathrm{kg} \mathrm{ha}^{-1}\right)$ in BARI Jharsheem-1 in 15 November sowing which was statistically similar with same variety in 30 November sowing $\left(1680 \mathrm{~kg} \mathrm{ha}^{-1}\right)$ and also with BARI Jharsheem-2 on 15 November sowing. The lowest seed yield (421 $\left.\mathrm{kg} \mathrm{ha}^{-1}\right)$ was produced in BARI Jharsheem-2 from 30 December sowing and it was statistically similar with BARI Jharsheem-3 at the same date. The highest seed yield was obtained from November sowing might be due to favourable optimum temperature resulting better vegetative growth of plants which led to better flowering and pod setting that resulted in maximum seed yield of French bean. This finding is also in agreement with the findings of Mohanty et al., 2001. There was a trend of decreasing seed yield and yield components with the advancement of sowing date from 30 November sowing due to increased in temperature. The results obtained in the present study are conformity with Mouho-uche et al., 1998; Nielsen and Nelson, 1998; Ferreira et al., 2000. 
Table 4. Seed yield and yield components of different French bean varieties under different sowing dates

\begin{tabular}{cccccccc}
\hline $\begin{array}{c}\text { Sowing date } \\
\times \text { variety }\end{array}$ & $\begin{array}{c}\text { Plant } \\
\text { height }(\mathrm{cm})\end{array}$ & $\begin{array}{c}\text { Flowers } \\
\text { plant } \\
(\text { no. })\end{array}$ & $\begin{array}{c}\text { Pods/ plant } \\
\text { (no.) }\end{array}$ & $\begin{array}{c}\text { Pods } \\
\text { Abscission } \\
(\%)\end{array}$ & $\begin{array}{c}\text { Seeds pod } \\
\text { (no.) }\end{array}$ & $\begin{array}{c}\text { 100-seed } \\
\text { weight (g) }\end{array}$ & $\begin{array}{c}\text { Seed yield } \\
\left(\mathrm{Kg} \mathrm{ha}^{-1}\right)\end{array}$ \\
\hline $\mathrm{D}_{1} \times \mathrm{V}_{1}$ & 52.33 & 39.01 & 15.83 & 59.29 & 5.00 & 24.73 & 1734.00 \\
$\mathrm{D}_{1} \times \mathrm{V}_{2}$ & 43.93 & 42.56 & 14.43 & 66.08 & 4.00 & 23.73 & 1620.33 \\
$\mathrm{D}_{1} \times \mathrm{V}_{3}$ & 45.73 & 25.10 & 8.93 & 64.06 & 4.00 & 35.26 & 1501.67 \\
$\mathrm{D}_{2} \times \mathrm{V}_{1}$ & 44.73 & 38.51 & 14.93 & 61.21 & 5.00 & 23.47 & 1680.67 \\
$\mathrm{D}_{2} \times \mathrm{V}_{2}$ & 39.47 & 40.72 & 12.50 & 69.27 & 4.00 & 22.57 & 1460.67 \\
$\mathrm{D}_{2} \times \mathrm{V}_{3}$ & 44.13 & 25.34 & 9.27 & 63.04 & 4.00 & 34.93 & 1354.67 \\
$\mathrm{D}_{3} \times \mathrm{V}_{1}$ & 34.17 & 23.44 & 8.97 & 61.72 & 5.00 & 22.87 & 1567.33 \\
$\mathrm{D}_{3} \times \mathrm{V}_{2}$ & 31.33 & 25.27 & 6.50 & 74.29 & 4.00 & 17.50 & 1114.33 \\
$\mathrm{D}_{3} \times \mathrm{V}_{3}$ & 34.80 & 19.93 & 5.83 & 70.55 & 4.00 & 29.60 & 1164.33 \\
$\mathrm{D}_{4} \times \mathrm{V}_{1}$ & 24.93 & 19.80 & 7.00 & 64.16 & 4.00 & 19.17 & 914.00 \\
$\mathrm{D}_{4} \times \mathrm{V}_{2}$ & 22.33 & 15.03 & 3.47 & 76.93 & 3.00 & 16.45 & 421.00 \\
$\mathrm{D}_{4} \times \mathrm{V}_{3}$ & 26.47 & 15.57 & 4.02 & 73.98 & 3.00 & 27.80 & 562.00 \\
\hline $\mathrm{LSD}_{(0.05)}$ & 2.59 & 2.98 & 1.25 & 2.94 & 0.37 & 1.73 & 143 \\
$\mathrm{CV}(\%)$ & 4.03 & 6.26 & 7.76 & 4.50 & 4.89 & 4.03 & 6.57 \\
\hline
\end{tabular}

$\mathrm{V}_{1=}$ BARI Jharsheem -1, V2= BARI Jharsheem -2, $\mathrm{V}_{3=}$ BARI Jharsheem -3, $\mathrm{D}_{1=1} 15$ November,

$\mathrm{D}_{2=} 30$ November, $\mathrm{D}_{3=} 15$ December, $\mathrm{D}_{4=} 30$ December

\section{CONCLUSION}

French bean varieties sown on November to December showed the variability with respect to the flowering, flowering duration, number of pods setting and seed yield. But 15 to 30 November sowing would be the optimum time for getting maximum seed yield of BARI Jharsheem-1 and this variety could be sown upto December with reasonable yield.

\section{REFERENCE}

Ali, M. and Tripathi, A. 1988. Dry matter accumulation and yield of winter French bean as influenced by genotypes, nitrogen level and plant population. Indian Journal of Agricultural Science, 58 (4): 263-267

Boyer, J.S. 1982. Plant Productivity and Environmental Science, 218: 443-448

Deore, B.P., Bharud, R.W. and Kharde, V.N. 1989. Physiological basis for yield Differences in chickpea under different seedling periods. Annals of Plant Physiology, 3(2): $181-187$ 
Ferreira, M.E., Ferreira, A., Monteiro, A.A., de Meloe Abreu J.P. and Bianco, V.V. 2000. A simple weather driven model to determine harvest date of green beans for freezing using quantitative and qualitative criteria. Acta Horticulture, 533: 489-495

Fisher, N.M. 1980. The effect of time on planting on four beans (Phaseolus vulgaris) genotypes in Kenya. Journal of Agricultural Science. Cambodia, 59(2): 401-408

Graham, P.H. 1979. Influence of temperature on growth and nitrogen fixation in cultivars of (Phaseolus vulgaris L.) inoculated with Rhizibium. Journal of Agriculture Sciences, 93 (2):365-370

Gross, Y. and Kigel, J. 1994. Differential sensitivity to high temperature of stages in the reproductive development of common bean (Phaseolus vulgaris L.) Field Crops Research, 36: 201-212

Helena, Ł., and Brodaczewska, A. 2007. The influence of environmental factors on flowering of French bean (Phaseolus vulgaris) Acta Agrobotanica, 60 (2):153-159

Heitholt, J.J., Egli, D.B. and Leggett, J.E. 1986. Characteristics of reproductive abortion in soybean. Crop Science, 26:589-595

Ibarra, P., Barnhart, F. J., Ehdaie, D., Knio, B., Waines, K.M. and J.G. 1999. Effects of insect tripping on seed yield of common bean. Crop Science, 39: 428-433

Mohanty, S. K., Baisakih, B., Dikshit, U. K. and Bhol, B. 2001. Kalamung, a promising local mungbean cultivar. Environment Ecology, 16(1): 222-223

Nonnecke, R. Vegetables Production. Van Notrand Reinhold. New York, USA, 1989

Mouhouche, B., Ruget, F. and Delécolle, R. 1998. Effects of water stress applied at different phonological phases on yield components of dwarf bean (Phaseolus vulgaris L.). Agronomie, 18: 197-205

Nielsen, D.C. and Nelson, N.O. 1998. Blackbean sensitivity to water stress at various growth stages. Crop Science, 38: 422-427

Saha, R.R. 2003. Physiological aspects of yield and seed quality of mungbean (Vigna radiata (L) Wilczek Ph.D. Thesis, Department of Agronomy, Bangabandhu Sheikh Mujibur Rahman Agricultural University, Salna, Gazipur.

Savin, R. and Nicolas, M.E.1996. Effect of short periods of drought and high temperature on grain growth and starch accumulation of two malting barley cultivars. Australian Journal of Plant Physiology, 23: 201-210

Sharma, V.K., Soroch, K. and Singh, C.M. 1997. Influence of time of sowing yield of Frenchbean (Phaseolus vulgaris) under dry temperate zone of Himachal Pradesh. Indian Journal of Agronomy, 42: 322-326

Srivastava, B. and Singh, R.P. 1989. Morphological response of garden pea to sowing dates. II. Growth analysis. Indian Journal of Horticulture, 46: 382-389

Summer, F.R.J. and Roberts, E.H. 1984. Phaseolus vulgaris. [In:] Handbook of flowering A.H. Halevy (ed). CRC, Press Boca Raton. Fl.: 139-147 